\title{
Tekst i jego dodatki, dodatki i tekst \\ - od supersytetmu rozrywkowego do uniwersum kulturowego
}

\author{
Konrad Dominas
}

Tekst literacki wydaje się współcześnie nieustannie zapośredniczany przez nowe media oraz literaturę i kulturę popularną. Przestrzenie te nadają nowy ton relacjom między tekstem a jego otoczeniem, w nowej perspektywie stawiając pytanie o to, czym jest dodatek do tekstu i jaką pełni on funkcję. W wyniku tych zmian powstaje swoisty system różnorakich elementów - literatura, film, animacje, serwisy internetowe, media społecznościowe, komiks itp. którego wyznacznikiem jest powolne zacieranie się granic między poszczególnymi częściami zbioru. Tekst przestaje być w tym układzie punktem odniesienia a staje się np. dodatkiem do filmu lub animacji komputerowej.

Opisanie powyższych relacji jest zadaniem nie tylko trudnym, ale i ryzykownym. Najważniejszym problemem staje się interdyscyplinarność zagadnienia oraz brak odpowiedniej metodologii. Pomimo tego, przedstawiciele różnych dyscyplin naukowych podejmują próby wypracowania teorii łączącej teksty literackie, nowe media i popkulturę a następnie nadania im za pomocą rozmaitych narzędzi badawczych jednorodnego charakteru. Cechą wyróżniającą owe teorie jest swoista unifikacja, polegająca na wypracowaniu terminologii, która swym zakresem objęłaby całą, skomplikowaną problematykę. I tak Marsha Kinder w pracy Playing with Power in Movies, Television, and Video Games. From Muppet Babies to Teenage Mutant Ninja Turtles z $1991 \mathrm{roku}^{1}$, wprowadza dwa niezwykle istotne pojęcia: supersystem transmedialnej interaktywności (supersystem of transmedia intertextuality) oraz supersystem rozrywko-

\footnotetext{
${ }^{1}$ M. Kinder, Playing with Power in Movies, Television, and Video Games: From Muppet Babies to Teenage Mutant Ninja Turtles, Berkeley 1991. O supersystemie rozrywkowym w polskiej literaturze przedmiotu zob. A. Mazurkiewicz, Teksty kultury cyberpunkowej w systemie rozrywkowym, „Studia Pragmalingwistyczne” 2011, r. III, s. 30-50;

Z. Wałaszewski, Papierowy jednorożec, klubówka i Łowca Androidów. O powstawaniu supersystemu rozrywkowego, [w:] Literatura i kultura popularna. Badania, analizy, interpretacje, red. A. Gemra, Wrocław 2015, s. 217-230.
} 
wy (supersystem of entertainment). Henry Jenkins w Kulturze konwergencji. Zderzenie starych i nowych mediów (2007) ${ }^{2}$ używa terminu opowiadanie transmedialne, uściślając je w dalszych częściach pracy jako opowiadanie synergiczne. Natomiast w antropologii kulturowej oraz w pracach poświęconych literaturze i kulturze popularnej stosuje się pojęcie uniwersum kulturowego ${ }^{3}$.

Wybór powyższych terminów nie jest przypadkowy. Układają się one w następujący algorytm: intertekstualność $\rightarrow$ supersystem transmedialnej interaktywności $\rightarrow$ opowiadanie synergiczne $\rightarrow$ uniwersum kulturowe. Pierwsze trzy elementy zbioru ilustruję w niniejszym artykule trylogią Lilly i Leny Wachowski: Matrix, Matrix Reaktywacja, Matrix Rewolucje, natomiast uniwersum kulturowe rozmaitymi przykładami z szeroko pojętej kultury popularnej. Zaproponowana terminologia nie tylko odnosi się do procesów między tekstami a ich otoczeniem, lecz także w nowym świetle sytuuje pojęcia intertekstualności, transtekstualności, pantekstualności oraz relacje, które za Ryszardem Nyczem możemy określić jako tekst-tekst, tekst-gatunek, tekst-rzeczywistość ${ }^{4}$.

Zależności tekst-dodatek/tekst-otoczenie ukazuję zatem w zupełnie innym kontekście: kontekście systemu, w którym tekst stanowi jeden z elementów nieustannych odniesień do pozostałych części zbioru i odwrotnie, pozostałe części zbioru są nieustannie uzupełniane przez tekst. Jest to zatem droga, która z perspektywy badacza, nawet szeroko pojętej tekstualności, wydać się może końcowym etapem przemian.

\section{Od Matriksa do supersystemu rozrywkowego}

W jednym z początkowych fragmentów filmu Matrix (The Matrix, reż. Lilly Wachowski i Lana Wachowski, Australia, USA 1999), Thomas Anderson, ukrywający się pod hakerskim pseudonimem Neo, otrzymuje trzy elektroniczne wiadomości: „Obudź się, Neo...” („Wake up. Neo...), „Matrix Cię więzi...” („The Matrix has you...”), „Podążaj za białym królikiem” („Follow the white rabbit...”) ${ }^{5}$. Kilka chwil później główny bohater sięga po książkę, w której ukrywa nośniki z nielegalnie zdobytymi danymi. Za dwa tysiące dolarów jeden z nich wręcza kontrahentowi Choiowi. Fragment kończy scena rozgrywająca się w klubie, w którym Neo pośród dźwięków psychodelicznej muzyki spotyka po raz pierwszy Trinity. Opisany fragment filmu rozgrywa się między 7 a 12 minutą filmu. W ciągu zaledwie 5 minut odbiorca otrzymuje niezwykle wymowny intertekst, którego rozszyfrowanie przebiega na trzech poziomach oraz w dwóch wymiarach: znaczeniowym (interpretacyjnym) i medialnym (mechanicznym).

\footnotetext{
${ }^{2}$ H. Jenkins, Kultura konwergencji: zderzenie starych i nowych mediów, przeł. M. Bernatowicz, M. Filiciak, Warszawa 2007.

${ }^{3}$ Pojęcie uniwersum kulturowego stosowane jest w różnych kontekstach i perspektywach. Zob. Literatura i kultura popularna...; Literatura i kultura popularna. Badania i metody, red. A. Gemra, A. Mazurkiewicz, Wrocław 2014; Dawno temu w Galaktyce Popularnej, red. A. Jawłowski, Warszawa 2010; J.Z. Lichański, W. Kajtoch, B. Trocha, Literatura i kultura popularna. Metody: propozycje i dyskusje, Wrocław 2015.

${ }^{4}$ R. Nycz, Intertekstualność i jej zakresy: teksty, gatunki, światy, [w:] egoż, Tekstowy świat, Kraków 2000, s. 87-100. Warto jednak w kontekście nowych analiz odnoszących się do tekstualności pamiętać o słowach Jurija M. Łotmana: „W różnych okresach nauka wyrzuca na powierzchnię słowa takiego właśnie rodzaju, które wskutek lawinowego wzrostu ich występowania w tekstach naukowych zatracają swą niezbędną jednoznaczność. Słowa te nie tyle ściśle terminologicznie oznaczają jakieś pojęcie naukowe, ile stanowią hasło wywoławcze aktualnego problemu i wskazują na obszar, na którym się rodzą nowe idee naukowe”. J.M. Łotman, Tekst w tekście, przeł. J. Faryno, „Literatura na Świecie” 1985, nr 3, s. 325.

${ }^{5}$ Wszystkie cytaty i tłumaczenia pochodzą z następującego wydania filmu: Matrix, DVD, Galapagos 2010.
} 
Pierwszy poziom intertekstualnych odniesień dotyczy białego królika przedstawionego w postaci tatuażu na plecach jednej z partnerek Choia. Jest to bezpośrednie i łatwe do rozszyfrowania nawiązanie do Alicji w Krainie Czarów Lewisa Carrolla. Poziom drugi związany jest z tytułem książki, w której Neo ukrywa skradzione informacje. W filmie ukazany zostaje jedynie jej tytuł. Tą książką jest Simulacra and Simulation Jeana Baudrillarda ${ }^{6}$. Poziom trzeci wykracza poza ramy Matriksa i polega na połączeniu poszczególnych dialogów z muzyką - utworem $\mathrm{Du}$ hast niemieckiej grupy Rammstein ${ }^{7}$. Znaczenie w tym przypadku ma zarówno warstwa słowna utworu, jak i teledysk wyreżyserowany przez Philippa Stölzla ${ }^{8}$.

Powyższe nawiązania przebiegają w dwóch wymiarach. Wymiar znaczeniowy (interpretacyjny) pozwala odbiorcom dostrzec w filmie jego główne założenia i swoistą filozofię, mieszczące się między przeciwstawnymi sobie pojęciami:

- jawa - sen: „Zdarza ci się czasem, że nie wiesz, czy to sen, czy jawa” - słowa Neo do Choia,

- rzeczywistość - fikcja - książka Simulacra and Simulation,

- wolność - niewola - komunikat „Matrix Cię więzi” i później „Obserwują Cię. (...) Wysłuchaj mnie. Wiem, po co tu przyszedłeś. Wiem, czym się zajmujesz. Czemu nie śpisz. Dlaczego jesteś sam i całe noce ślęczysz przy komputerze. Szukasz go" - słowa Trinity do Neo,

- świat realny - świat magii - komunikat „Podążaj za białym królikiem”.

Trzypoziomowe rozszyfrowywanie znaczeń opiera się więc na powiązaniu poszczególnych fragmentów filmu ze znanymi z literatury i muzyki odniesieniami. W pierwszym przypadku mamy do czynienia ze wspomnianą już Alicja w Krainie Czarów, w drugim z pracą Jeana Baudrillarda i podstawami jego filozofii, w trzecim z odniesieniami do tekstu piosenki zespołu Rammstein (szczególnie słowa: „Du.../Du hast.../Du hast mich.../Du hast mich.../Du hast mich gefragt/Du hast mich gefragt/Du hast mich gefragt und ich hab' nichts gesagt") ${ }^{9}$ oraz do niezwykle wymownego teledysku tej grupy inspirowanego filmem Quentina Tarantino Wściekłe psy (Reservoir Dogs, reż. Quentin Tarantino, USA 1992).

Wymiar medialny dotyczy mechanizmów, za pomocą których odbiorcy udaje się rozszyfrować opisane powyżej znaczenia. Mechanizmy te nie tylko opierają się na jego wiedzy (autorstwo książki Simulacra and Simulation), lecz także na spostrzegawczości i refleksie. To te właśnie umiejętności pozwalają wyłapać krótkie, zaledwie kilkusekundowe sekwencje filmu. Wymiar

${ }^{6}$ J. Baudrillard, Simulacra and Simulation, Ann Arbor 1994. Oryginalne wydanie francuskie pochodzi z roku 1981 (Éditions Galilée), polskie z 2005 roku (Wydawnictwo Sic!).

${ }^{7}$ Utwór ten nie występuje na ścieżce dźwiękowej filmu, został dołączony do oficjalnej płyty The Matrix: Music from the Motion Picture (Warner Bros/Maverick, 1999) zawierającej 12 utworów związanych z produkcją Lilly i Lany Wachowskich.

${ }^{8}$ Rammstein, Du hast, reż. Philipp Stölzl, oficjalna strona teledysku: <https://www.youtube.com/ watch?v=W3q8Od5qJio> [dostęp: 4 czerwca 2016].

${ }^{9}$ Piosenka Du hast pochodzi z roku 1997, jej producentem jest Jacob Hellner i Rammstein. Utwór, którego autorem tekstu jest Till Lindemann, został wydany przez Motor Music. 
medialny wymaga zatem od odbiorcy nawet kilkakrotnego obejrzenia poszczególnych scen: fragment po fragmencie, a być może klatka po klatce.

Najciekawszym zagadnieniem omawianej części Matriksa, jest jednak rola, jaką odgrywają w filmie liczne cytacje i nawiązania. Najprostszym wytłumaczeniem tego problemu jest potraktowanie wszystkich wskazówek jako drogowskazów służących znalezieniu odpowiedzi na temat istoty Matriksa - komputerowego systemu funkcjonującego w celu pozyskiwania przez maszyny energii. Morfeusz pyta „Czym jest Matrix? Władzą. To cyfrowy świat stworzony, by nad nami panować i zmieniać ludzi w to", po tych słowach pokazuje on Neo baterię. Świat realny istnieje poza systemem, to, czego doświadczają mieszkańcy Matriksa, jest zaledwie ułudą wygenerowaną przez program komputerowy. Niezwykle wymowne okazuje się w tym kontekście nawiązanie do filozofii Jeana Badrillarda i pojęcia symulakrów. W ten sposób rozszyfrowanie poszczególnych wskazówek przypomina grę, jaką scenarzyści i reżyserzy prowadzą $\mathrm{z}$ widzem. Warto jednak powrócić do medialnego wymiaru Matriksa. Połączenie wszystkich elementów w logiczną całość wymaga od odbiorcy kilkukrotnego obejrzenia filmu, a następnie odniesienia wszystkich zdobytych informacji do świata muzyki, literatury, sztuki itp.

Powyższa analiza przypomina konwencję lektury palimpsestowej, do której nawiązuje Gérard Genette, omawiając pojęcie hipertekstualności ${ }^{10}$. To właśnie hipertekstualność jako szczególny rodzaj transtekstualności „ma na swój sposób wiele wspólnego z majsterkowaniem (bricolage)”11; „(..) jest sztuką tworzenia czegoś nowego z czegoś starego” ${ }^{12}$. Idąc dalej tym tropem, moglibyśmy zapytać, co w tej konwencji jest hipertekstem, a co hipotekstem i jakie relacje występują między poszczególnymi elementami? Rozmaite nawiązania w Matriksie można odczytywać przede wszystkim jako intertekstualne, chociaż wielu badaczy zaproponowałoby zapewne dyskusję wokół tradycyjnych filologicznych badań wpływów i zależności oraz komparatystyki ${ }^{13}$. Warto zaznaczyć, iż większość produktów kultury popularnej traktuje się jako mozaikę ogromnej liczby motywów i toposów literackich, zawsze wtórnych wobec pierwowzoru ${ }^{14}$. Wszystkie nawiązania i cytacje stają się zatem jednym z podstawowych mechanizmów współczesnej kultury ${ }^{15}$.

Matrix stał się pewnego rodzaju fenomenem kultury, zjawiskiem w oczach wielu odbiorców wręcz kultowym. Według koncepcji Marshy Kinder film ten można opisać jako supersystem rozrywkowy, a dokładniej jako supersystem of transmedia intertextuality. Kinder pojęcie intertekstualności wpisuje w kontekst medioznawczy, pomimo tego że część metodologiczną rozpoczyna od nawiązań do tekstów Julii Kristevej ${ }^{16}$. Według autorki

\footnotetext{
${ }^{10} \mathrm{G}$. Genette, Palimpsesty. Literatura drugiego stopnia, przeł. A. Milecki, [w:] Wspótczesna teoria badań literackich za granicq, oprac. H. Markiewicz, t. 4, cz. 2, Kraków 1992, s. 363-364.

${ }^{11}$ Tamże, s. 363.

${ }^{12}$ Tamże.

${ }^{13}$ H. Markiewicz, Odmiany intertekstualności, [w:] tegoż, Wymiary dzieła literackiego, Kraków 1996, s. 218. Por. M. Głowiński, O intertekstualności, „Pamiętnik Literacki” 1996, LXXVII, z. 4, s. 76-77.

${ }^{14}$ Zob. A. Gemra, Wprowadzenie [do:] Literatura i kultura popularna..., s. 7-13.

${ }^{15}$ W kontekście Matriksa szczególnie widoczne są np. odniesienia do literatury cyberpunkowej. Zob.

A. Mazurkiewicz, Z problematyki cyberpunku. Literatura - sztuka - kultura, Łódź 2014, s. 337-340.

${ }^{16} \mathrm{M}$. Kinder, Playing with Power in Movies..., s. 1-2.
} 
intertekstualność oznacza, że każdy pojedynczy tekst (taki rodzaj sztuki, jak film lub powieść albo bardziej powszechny tekst jak artykuł w gazecie, billboard albo zwyczajna uwaga słowna) jest częścią szerszego kulturowego dyskursu i z tego powodu musi być odczytywany w relacji z innymi tekstami i ich rozmaitymi tekstualnymi strategiami i ideologicznymi założeniami ${ }^{17}$.

Transmedia intertextuality jest zatem swoistym uzupełnieniem intertekstualności o nowy system znaków: film, animacje, gry komputerowe, telewizję śniadaniową itp. Supersystem of transmedia intertextuality oznacza więc nową transmedialną przestrzeń intertekstualności, w której rozpoczyna się wspomniany we wstępie proces powolnego zacierania się granic między poszczególnymi elementami systemu, który Kinder nazywa supersystemem rozrywkowym $^{18}$. Jego cechą charakterystyczną jest to, że wszelkie nawiązania intertekstualne odwołują się do ogólnej wiedzy odbiorców. Znaczenie ma nie tyle znajomość danego tekstu, ile umiejętność odnalezienia go w przestrzeni medialnej i połączenia go z innymi tekstami. Warto jednak zaznaczyć, że przestrzeń medialna w ujęciu Kinder odsyła czytelnika przede wszystkim do telewizji i świata gier komputerowych - Playing with Power in Movies, Television... została wydana w roku 1991, nie odnosi się więc do mediów skupionych wokół Internetu ${ }^{19}$.

\section{Od supersystemu rozrywkowego do opowiadania transmedialnego}

Pierwsza część Matriksa tworzyła pewną zamkniętą całość, a liczne odwołania i zapożyczenia w połączeniu z efektami specjalnymi i czterema Oscarami uczyniły z niej jeden z najbardziej kultowych filmów końca XX wieku ${ }^{20}$. W odróżnieniu od części pierwszej, Matrix Reaktywacja (The Matrix Reloaded, reż. Lilly Wachowski i Lana Wachowski, Australia, USA 2003) i Matrix Rewolucje (The Matrix Revolutions, reż. Lilly Wachowski i Lana Wachowski, Australia, USA 2003) wydają się niedokończone, a niekiedy wręcz niezrozumiałe. Gdyby brać pod uwagę jedynie opinie krytyków, musielibyśmy uznać, że filmy te to typowy przykład nieudanej kontynuacji pierwszej części. Produkcji tych broni Henry Jenkins.

\footnotetext{
${ }^{17}$ „(...) intertextuality has come to mean that any individual text (whether an artwork like a movie or novel, or a more commonplace text like a newspaper article, billboard, or casual verbal remark) is part of a larger cultural discourse and therefore must be read in relationship to other texts and their diverse textual strategies and ideological assumptions". Tamże, s. 2.

${ }^{18} \mathrm{~W}$ ramach prowadzonego przeze mnie fakultetu Wspótczesna kultura jako supersystem rozrywkowy studenci Wydziału Filologii Polskiej i Klasycznej Uniwersytetu im. Adama Mickiewicza w Poznaniu zaproponowali następujące supersystemy rozrywkowe: Angry Birds, powieść Władca pierścieni J.R.R Tolkiena, współczesne kampanie wyborcze, serial Miasteczko Twin Peaks (Twin Peaks, reż. D. Lynch, M. Frost, USA 1990-1991), serial Gra o tron (Game of Thrones, reż. D. Benioff, D.B. Weiss, USA 2011-). Zajęcia były prowadzone w roku akademickim 2015/2016.

${ }^{19}$ Najpopularniejsza dziś usługa Sieci - World Wide Web został opracowana przez Tima Bernersa-Lee i Roberta Cailliau w 1989 roku w Europejskiej Organizacji Badań Jądrowych (CERN). W 1993 roku pojawiła się pierwsza przeglądarka internetowa, Mosaic, niezbędna do przeglądania stron internetowych. Aplikacja powstała w National Center for Supercomputing Applications (NCSA) i stała się jednym z najważniejszych elementów późniejszej komercjalizacji Sieci. Dopiero w 1995 roku amerykańska Federalna Rada Sieci Komputerowych (Federal Networking Council - FNC) wprowadziła definicję Internetu, zaś Google pojawiło się w WWW w 1997 roku. Zob. T. Berners-Lee, The World Wide Web: Past, Present and Future, <https://www.w3.org/People/BernersLee/1996/ppf.html> [dostęp: 4 czerwca 2016]; 〈http://www.google.com/about/company/history/> [dostęp: 4 czerwca 2016]; <https://www.w3.org/People/Berners-Lee/1996/ppf.html> [dostęp: 4 czerwca 2016]; <http:// www.internetsociety.org/internet/what-internet/history-internet/brief-history-internet> [dostęp: 4 czerwca 2016].

${ }^{20}$ W 2000 roku Matrix otrzymał cztery Oscary za najlepsze efekty specjalne (John Gaeta, Janek Sirrs, Steve Courtley, Jon Thum), najlepszy dźwięk (David E. Campbell, David Lee, Gregg Rudloff, John T. Reitz), najlepszy montaż (Zach Staenberg) oraz najlepszy montaż dźwięku (Dane A. Davis).
} 
Sądzę jednak - pisze autor - iż nie mamy jeszcze dobrych kryteriów estetycznej oceny dzieł wykorzystujących różne media. Zbyt mało było w pełni transmedialnych opowiadań, by twórcy mogli z wystarczającą pewnością ocenić, jak wygląda najlepsze wykorzystanie tej nowej formy narracji lub by krytycy i konsumenci wiedzieli, jak rozmawiać o tym, co działa lub nie działa wewnątrz takiej marki ${ }^{21}$.

Według Jenkinsa trylogia Lilly i Lany Wachowskich otwiera przed odbiorcami nowy typ narracji: opowiadanie transmedialne, którego istotą jest fakt, iż rozwija się ono na różnych platformach medialnych, „a każdy tekst stanowi wyróżniającą się i ważną część całości”22. Matrix jako opowiadanie transmedialne składa się z następujących elementów: wspomnianych trzech produkcji filmowych (1999-2003); filmu dokumentalnego The Matrix Revisited (reż. Josh Oreck, USA 2001); gier komputerowych: Enter the Matrix (Shiny Entertainment, USA 2003) wyprodukowanej przez Davida Perry'ego, The Matrix Online (Monolith Productions, USA 2005) według scenariusza Paula Chadwicka, The Matrix: Path of Neo (Shiny Entertainment, USA 2005); dziewięciu krótkometrażowych filmów animowanych pt. Animatrix (Japonia, USA 2003) ${ }^{23}$; całej serii książek i komiksów, m.in. The Art of the Matrix Spencera Lamma (Newmarket Press, 2000), Enter The Matrix: Official Strategy Guide Douga Walsha (Brady Games, 2003), The Matrix Comics wydawanych przez Titan Books między 2003 a 2005 rokiem. Jak pisze Jenkins „Matrix integruje niezliczone teksty kultury, by stworzyć opowieść tak wielką, że nie zmieściłaby się w jednym tylko środku przekazu"24.

Opowiadanie transmedialne niekiedy określane przez Jenkinsa jako opowiadanie synergiczne ${ }^{25}$ wpisuje się w trzy główne koncepcje jego książki: konwergencję mediów, kulturę uczestnictwa oraz zbiorową inteligencję. Pierwszy z tych terminów obejmuje rozmaite zmiany w przestrzeni technologicznej, przemysłowej, kulturowej i społecznej, które doprowadziły do nieustannego przepływu informacji (treści) między różnymi platformami medialnymi ${ }^{26}$. W odróżnieniu od wcześniejszych teoretyków mediów, konwergencja jest dla Jenkinsa przede wszystkim konceptem kulturowym, angażującym niezliczone rzesze konsumentów w procesy związane z archiwizowaniem, komentowaniem, przejmowaniem i redystrybuowaniem treści medialnych ${ }^{27}$. Jego tezy w sposób oczywisty nawiązują do koncepcji tzw. kanadyjskiej szkoły

\footnotetext{
${ }^{21}$ H. Jenkins, Kultura konwergencji..., s. 96.

${ }^{22}$ Tamże, s. 95.

${ }^{23}$ Polska wersja ukazała się w tym samym roku. Serię tworzą następujące tytuły: Ostatni lot Ozyrysa, Drugie odrodzenie, część I, Drugie odrodzenie, część II, Historia ucznia, Program, Rekord świata, Nawiedzony dom, Opowieść detektywa, Zniewolony. Dokładne dane na temat reżyserów i scenarzystów, zob. <http://www.imdb.com/title/ tt0328832/> [dostęp: 4 czerwca 2016].

${ }^{24} \mathrm{H}$. Jenkins, Kultura konwergencji..., s. 95. Innym przykładem opowiadania transmedialnego może być Immortals. Bogowie i herosi Tarsema Singha (Immortals, USA 2011). Wraz z filmem Archaia Entertainment wydało komiks Immortals. Gods and Heroes (Los Angeles, 2011) - zbiór dziewięciu opowiadań podzielonych na dwie części: Gods (pięć opowiadań) i Heroes (cztery opowiadania). Opowiadania te nie tylko rozwijają poruszone w filmie wątki, lecz także modyfikują je i przekształcają. Dopiero przeczytanie komiksu pozwala czytelnikowi w pełni zrozumieć konflikt między Olimpijczykami i Tytanami. Dokładna analiza filmu w kontekście recepcji literatury antycznej i opowiadania transmedialnego zob. K. Dominas, Bogowie i herosi w kulturze popularnej na przykładzie produkcji Wolfganga Petersena „Troja” oraz Tarsema Singha „Immortals. Bogowie i herosi”,

[w:] Fantastyczność i cudowność. „Homo mythicus”. Mityczne wzorce tożsamości, red. B. Trocha,

G. Trębicki, H. Kubicka, Zielona Góra 2014, s. 79-86.

${ }^{25}$ Tamże, s. 100-107.

${ }^{26}$ Tamże, s. 9. Zob. również: <http://henryjenkins.org/2006/06/welcome_to_convergence_culture.html> [dostęp: 7 czerwca 2016].

${ }^{27}$ Tamże, s. 135.
} 
medioznawczej (Harold A. Innis, Eric A. Havelock, Walter J. Ong, J. Goody, M. McLuhan, Derrick de Kerchove), a w pewnym sensie są ich ucieleśnieniem, co jednak warte podkreślenia, nie powielają jednak typowego dla Marshalla McLuhana determinizmu technologicznego ${ }^{28}$. Konwergencja jest zmianą paradygmatu opierającego się na odejściu od treści wytwarzanych w obrębie jednego medium w stronę informacji przepływających przez różne kanały medial$\mathrm{ne}^{29}$. Zmiany te realizują się dzięki konsumentom i interakcjom między nimi, tworzącym oddolną kulturę uczestnictwa. Konsumpcję postrzega Jenkins jako proces kolektywny i za francuskim cyberteoretykiem Pierre’em Lévym wyznaje teorię, którą można streścić jednym zdaniem: „nikt z nas nie może wiedzieć wszystkiego, ale każdy z nas ma jakąś wiedzę”. ${ }^{30}$. Zdanie to w pełni oddaje koncepcję zbiorowej inteligencji, jednego z filarów nie tylko poglądów Jenkinsa, ale i całego trendu Web 2.0 ${ }^{31}$, do którego odwołuje się we wstępie autor Konwergencji mediów ${ }^{32}$.

Opowiadanie transmedialne łączy zatem różne platformy medialne w jeden wspólny organizm, któremu treść nadają konsumenci - użytkownicy systemu. Współpracują oni ze sobą dzięki nieustannej wymianie informacji oraz zbiorowej inteligencji. Warunkiem uczestnictwa $\mathrm{w}$ tym systemie jest ciągłe poszukiwanie i zaangażowanie w procesy wytwarzania nowych treści. Ponadto każdy element zbioru jest tak samo ważny, każdy powinien być w pełni poznany przez uczestnika procesu.

\section{Ku uniwersom kulturowym}

Współczesną kulturę popularną coraz częściej można określić jako zbiór nawzajem przenikających się i uzupełniających uniwersów kulturowych. Przykładami owych uniwersów mogą być: Gwiezdne wojny, Marvel, DC Comics, Lego, Transformers i wiele innych. Systemy te, obejmujące rozmaite elementy zbioru, pozostają w ciągłej i nieustannej nieokreśloności, której kształt nadają odbiorcy. Lepiej więc powiedzieć „uniwersum Lego Ninjago” niż „uniwersum klocków Lego”. Lepiej powiedzieć „uniwersum Marvela” niż „uniwersum komiksów Marvela", bowiem system ten tworzą filmy, animacje, zabawki, książki itp. ${ }^{33}$ Klocki, które do niedawna były główną materią firmy Lego, stały się obecnie częścią szerszego zbioru. Jedna z najnowszych propozycji duńskiej firmy, Lego Nexo Knights, oprócz 28 zestawów obejmuje: przewodniki po świecie Nexo Knights, bestiariusze, katalogi, komiksy ${ }^{34}$, filmy animowa-

\footnotetext{
${ }^{28}$ Zob. D. Mersch, Teorie mediów, przeł. E. Krauß, Warszawa 2010, s. 106-127; É. Maigret, Socjologia komunikacji i mediów, przeł. I. Piechnik, Warszawa 2012, s. 144-157.

${ }^{29} \mathrm{H}$. Jenkins, Kultura konwergencji..., s. 235.

${ }^{30}$ Tamże, s. 9. O pojęciu inteligencji zbiorowej, zob. R. Maciąg, Pragmatyka Internetu. Web 2.0 jako środowisko, Kraków 2013, s. 143-145.

${ }^{31}$ Web 2.0 jest pewnego rodzaju trendem w zakresie wykorzystania Internetu do tworzenia i zarządzania treścią, rozwoju technologii i aplikacji internetowych, takich jak Ajax, Google Maps i innych oraz generowania zysków dzięki udostępnianiu usług za darmo. Za A. Shuen, Web 2.0. przewodnik po strategiach, przeł. A. Stefański, Gwliwice 2009, s. 13-16.

${ }^{32} \mathrm{H}$. Jenkins, Kultura konwergencji..., s. VII.

${ }^{33}$ Por. S. Howe, Niezwykła historia Marvel Comics, przeł. B. Czartoryski, Kraków 2013. Zob. również <http://www. marvelcomics.pl/> [dostęp: 4 czerwca 2016].

${ }^{34}$ Prawa autorskie uprawniające do wydawania materiałów związanych z Lego Nexo Knights posiada Wydawnictwo Ameet. Zob. <http://www.ameet.pl/kategoria-produktu/katalog/lego/nexo-knights/> [dostęp: 4 czerwca 2016].
} 
ne $\mathrm{e}^{35}$ oraz cały arsenał marketingowych dodatków rozpowszechnianych za pomocą wszelkich możliwych kanałów dystrybucji, w tym w coraz większym zakresie za pomocą aplikacji internetowych ${ }^{36}$.

Dotychczasowe badania koncentrowały się na jednym, konkretnym produkcie kultury popularnej, a wszelkie jego uzupełnienia traktowano jako dodatki. Główny element uniwersum (film, zbiór komiksów, zestaw klocków lego, konkretny bohater, opowiadanie, tekst) tworzył więc jądro, wokół którego gromadziły się kolejne elementy, które interpretowano jako wtórne wobec pierwowzoru. Podobną sytuację można było zaobserwować, kiedy to określony tekst literacki, dzięki swej popularności, uzupełniany był o rozmaite dodatki: filmy, komiksy, reklamy, amatorskie filmy na YouTube, literaturę fan fiction itp. ${ }^{37}$

Pojęcie uniwersum rozumiane przeze mnie jako system naczyń połączonych niemal w całości eliminuje pojęcie „dodatku”. Dodatkiem może być np. koszulka z nadrukiem Optimusa Prime’a, kubek, pościel, zegarek itd. Jednym słowem wszechobecny marketing, który z jednej strony podtrzymuje sprzedaż, z drugiej zaś identyfikuje odbiorcę z konkretnym uniwersum. Jeśli jednak nadruk przedstawiałby nieznaną dotąd przygodę przywódcy Autobotów, wówczas koszulka/dodatek przestawałaby być uzupełnieniem uniwersum, a stałaby się jego częścią - tekstem wpisanym w system i pozostającym w nieustannych relacjach z innymi tekstami/elementami ${ }^{38}$.

W Kulturze konwergencji Jenkins stwierdza, iż opowiadanie transmedialne to sztuka tworzenia światów. „Aby w pełni doświadczyć każdego fikcyjnego świata - pisze uczony - konsumenci muszą przyjąć rolę myśliwych i zbieraczy, ścigających fragmenty opowieści na różnych kanałach medialnych porównujących między sobą notatki w sieciowych grupach dyskusyjnych i współpracujących" ${ }^{39}$. Jenkins za Pierre'em Lévym sięga po koncepcję „atraktora kulturowego", który powstaje w wyniku zacierania się granic między autorami i czytelnika$\mathrm{mi}$, producentami i widzami, twórcami i interpreterami ${ }^{40}$. Sam Jenkins posługuje się terminem „konsument” o wiele częściej niż „odbiorca”, „widz”, „czytelnik”. Pojęcie to jest dla

${ }^{35}$ W 2015 roku powstał duńsko-amerykański serial animowany Lego: Rycerze Nexo (Nexo Knights, 2015) emitowany w stacji Cartoon Network. Premiera polska miała miejsce pod koniec 2015 roku.

${ }^{36} \mathrm{Na}$ oficjalnej stronie Lego Nexo Knigts można nie tylko poznać świat bohaterów serii, lecz także zagrać w multimedialne gry, obejrzeć filmy animowane, a nawet wstąpić do Akademii Rycerzy Nexo Knights. Zob. <http://www.lego.com/pl-pl/nexoknights/products> [dostęp: 4 czerwca 2016].

${ }^{37} \mathrm{Na}$ szczególną uwagę zasługuje literatura fun fiction omawiana przez Jenkinsa w kontekście serii powieści o Harrym Potterze J.K. Rowling. H. Jenkins, Kultura konwergencji..., s. 168-193. Zob. również L. Gąsowska, Fan fiction. Nowe formy opowieści, Kraków 2015.

${ }^{38}$ Tajwańska firma ASUS, czołowy producent sprzętu komputerowego, której nazwa pochodzi od słowa „Pegasus” powiązała mitologię antyczną, taoizm (pięć cnót ASUS-a) oraz politykę korporacji opartą na regułach lean thinking . Na głównej stronie firmy czytamy: „Nazwa ASUS pochodzi od czterech ostatnich liter słowa Pegasus (Pegaz) - skrzydlatego konia z greckiej mitologii reprezentującego inspirację sztuki i nauki. ASUS uosabia siłę, kreatywność i czystość, których symbolem jest owo dostojne, mitologiczne stworzenie. Poprzez każdy produkt wypuszczony na rynek, firma wzbija się na nowe szczyty jakości i innowacyjności”, <https://www.asus.com/pl/ About_ASUS/Pochodzenie_slowa_ASUS/> [dostęp: 7 czerwca 2016]. Dokładna analiza przykładu w kontekście mitu i jego recepcji zob. K. Dominas, Internetowa recepcja mitu na przykładzie wybranych podań grecko-rzymskiej literatury, [w:] Studia mitoznawcze. Wspótczesna obecność mitu, red. I. Błocian, E. Kwiatkowska, Toruń 2012, s. 135-156.

${ }^{39}$ H. Jenkins, Kultura konwergencji..., s. 25.

${ }^{40}$ Tamże, s. 95. 
niego podstawowym wykładnikiem wpisującym się w kulturę uczestnictwa oraz, stanowiącą jej podstawę, inteligencję zbiorową ${ }^{41}$. Paul Levinson w pracy Nowe nowe media posunie się w tym kontekście o krok dalej. Zaproponuje on wprowadzenie nowego paradygmatu opierającego się na założeniu, iż podstawą współczesnych przemian w kulturze i społeczeństwie jest przejście od roli konsumenta treści do ich producenta ${ }^{42}$. To ta właśnie zmiana stanowi według Levinsona główną cezurę między nowymi a nowymi nowymi mediami.

W odróżnieniu od supersystemu rozrywkowego i opowiadania transmedialnego, uniwersum kulturowe jest w całości zapośredniczone przez nowe technologie, których mechanizmy i zasady funkcjonowania wyznaczają procesy tworzenia, przeglądania, interpretowania i udostępniania informacji. To właśnie informacje, a nie wiedza, stanowią zatem punkt wyjścia każdej analizy uniwersum. Nie istnieje w nim żadne konkretne jądro (tekst, film, animacja), wokół którego gromadzą się pozostałe elementy. System ten zakłada jedynie początek, który w historii uniwersum możemy określić np. jako premierę pierwszego filmu z serii Gwiezdnych wojen (Star Wars, reż. George Lucas, USA 1977). Użytkownik systemu, będący jednocześnie odbiorcą i nadawcą, sam określa sposób budowania uniwersum poprzez dodawanie kolejnych części zbioru. W środowisku uczestników może jedynie powstać dyskusja na temat kanoniczności tworzących ją produktów. Sposób łączenia poszczególnych elementów, dzięki nieograniczonemu i wieloplatformowemu (komputer, smartfon, telewizor itp.) dostępowi do sieci komputerowych staje się natychmiastowy. Wszystko i wszędzie można sprawdzić i zweryfikować. Istnieją setki miejsc (przestrzeni cyfrowych), gdzie można publikować, komentować i tworzyć nowe części systemu. Uniwersa stają się zatem zarówno nową formą opowiadania transmedialnego i supersystemu rozrywkowego, jak i ich skrajnym dopełnieniem.

\footnotetext{
${ }^{41}$ Inteligencję zbiorową krytykują w swoich pracach Andrew Keen oraz Wojciech Orliński. Zob. A. Keen, Kult amatora. Jak internet niszczy kulturę, wprowadzenie K. Krzysztofek, przeł. M. Bernartowicz, K. TopolskaGhariani, Warszawa 2007, s. 52-75; W. Orliński, Internet. Czas się bać, Warszawa 2013, s. 119-147.

${ }^{42}$ P. Levinson, Nowe nowe media, przeł. M. Zawadzka, Kraków 2010, s. 11-13. Levinson zwraca również uwagę na wzajemne, katalityczne relacje pomimo rywalizacji oraz na większe znaczenie nowych nowych mediów w stosunku do usług wcześniejszych: wyszukiwarek internetowych i poczty elektronicznej. Zob. tamże.
} 


\title{
SŁOWA KLUCZOWE:
}

\author{
uniwers u m \\ tekst \\ kulturowe
}

\section{tekstualność}

\section{supersystem rozrywkowy}

\begin{abstract}
AbSTRAKT:
Celem artykułu jest analiza nowych form relacji między tekstem a jego dodatkami: supersystemem rozrywkowym opartym na transmedialnej interaktywności (koncepcja Marshy Kinder); opowiadaniem transmedialnymo (koncepcja Henry'ego Jenkinsa); uniwersum kulturowym (koncepcja własna na podstawie bogatej literatury przedmiotu). Teorie te zostały zaprezentowane jako pewnego rodzaju proces polegający na zacieraniu się granic między tekstualnością a medialnością we współczesnej literaturze i kulturze popularnej.
\end{abstract}

\section{NOtA O AUTORzE:}

Konrad Dominas - adiunkt na Wydziale Filologii Polskiej i Klasycznej Uniwersytetu im. Adama Mickiewicza w Poznaniu. Filolog klasyczny i informatyk. Autor i redaktor prac z zakresu recepcji grecko-rzymskiego dziedzictwa w nowych mediach oraz w literaturze i kulturze popularnej, m.in. Antiquity in popular literature and culture (wspólna redakcja z E. Wesołowską i B. Trochą, Cambridge Scholars Publishing, 2016). Członek Komitetu Redakcyjnego „Literatury i Kultury Popularnej”. Obecnie pracuje nad habilitacją Internet jako nowa przestrzeń recepcji literatury antycznej. Na co dzień popularyzator starożytności i projektant witryn internetowych.| 